Vol. 1, No. 2, December 2020: p. 137-153 DOI: 10.18326/islah.vli2.137-153

ISSN : 2723-407X

Website: https://e-journal.iainsalatiga.ac.id/index.php/islah

\title{
Classical Islamic Political Thought: Study of Sunni Perspectives
}

\author{
Suyadi \\ Universitas Islam Negeri (UIN) Waliwongo \\ suyadisekawan4@gmail.com \\ Ahmad Fikri Sabiq \\ Institut Agama Islam Negeri (IAIN) Salatiga \\ ahmadfikrisabiq@gmail.com
}

Submission Track:

Received: 27-08-2020

Final Revision: 20-01-2021

Available Online: 20-01-2021

\begin{abstract}
The purpose of this study is to determine the Islamic political thought in classical Islam in the perspective of the Sunni sect. This research is a qualitative research which is library research. Data collection method is library data that has been selected, searched, presented and analyzed. This study uses data analysis techniques in the form of content analysis. Content analysis is a scientific analysis of the message content of a data. One of the characteristics of the classical era Islamic political thought is that it does not question the position of religion and state, whether integrated or separate. The debates that occurred in the classical era on the establishment of a state, the election of a head of state, and the conditions that a head of state must-have. Besides, political thought that develops also tends to be a response to the prevailing socio-political conditions. The emergence of Sunni ideology is a form of anxiety over the viewpoints developed by groups that tend to discredit the position of the Prophet's companions who are considered by some on the opposite side to have committed treason or treason. For Sunnis, leadership after the death of the Prophet Muhammad was open and not limited to ahl Bayt. A background that is considered appropriate and competent can be proposed as a leader. Thus, the appointment or appointment of the caliph as the legal ruler depends on the specific qualities possessed by the prospective leader.
\end{abstract}

Keywords: Islamic politics, classical era, Sunni.

\begin{abstract}
Abstrak
Penelitian ini bertujuan untuk mengetahui bagaimana pemikiran politik Islam di masa Islam klasik dalam perspektif aliran Sunni. Penelitian ini adalah penelitian kualitatif yang bersifat studi pustaka (library research). Metode pengumpulan data adalah data-data kepustakaan
\end{abstract}


yang telah dipilih, dicari, disajikan dan dianalisis. Penelitian ini menggunakan teknik analisi data berupa analisis isi (content analysis). Analisis isi merupakan analis ilmiah tentang isi pesan suatu data. Salah satu ciri pemikiran politik Islam era klasik adalah tidak mempersoalkan kedudukan agama dan negara, apakah terintegrasi atau terpisah. Perdebatan yang terjadi di era klasik pada pendirian sebuah negara, pememilihan kepala negara, dan syarat-syarat yang harus dimiliki kepala negara. Selain itu, pemikiran politik yang berkembang juga cenderung merupakan respon terhadap kondisi sosial politik yang terjadi. Kemunculan paham Sunni merupakan bentuk kegelisahan terhadap sudut pandang yang dibangun oleh kelompok-kelompok yang cenderung mendiskreditkan posisi sahabat Nabi yang dianggap oleh sebagian kalangan yang berseberangan telah melakukan pengkhianatan atau makar. Bagi Sunni, kepemimpinan setelah wafatnya Nabi Muhammad bersifat terbuka tidak terbatas menjadi milik ahl bayt. Latar belakang yang dianggap layak dan kompeten maka bisa diusulkan menjadi pemimpin. Jadi, penunjukan atau pengangkatan khalifah sebagai penguasa yang sah tergantung pada kualitas spesifik yang dimiliki calon pemimpin.

Kata Kunci: Politik Islam, masa klasik, Sunni.

\section{INTRODUCTION}

Islamic politics in history is a very interesting theme to discuss. In the political practice of Muslim-populated countries, there is a long tug of war and debate. Broadly speaking, several debates often surround the journey of political Islam. The first is about political power, especially in the classical and medieval era. This situation then created fragmentation within the Muslim community which in turn gave birth to two major groups, namely Shia and Sunnis. ${ }^{1}$

For Islam, this dynamic gave birth to many thinkers who tried to pour ideas both to solve problems or to strengthen the arguments of their respective groups. These various formulations of the relationship between Islam and politics are the result of the systematization of Islamic teachings and the traditions of Muslims in the political field. Historical data shows that there are many competing phenomena of religious thought groups, both theology, and jurisprudence, in seizing influence and patronage with the authorities.

The interaction between religion and politics in Islamic history can be traced back to the era of the Prophet Muhammad. On the one hand, the Prophet served as a supreme religious leader and also succeeded in practicing government and state administration by building a political community. The climax was when the establishment of the state of Medina was followed by the Medina Agreement (dustur al-Madinah) which was carried out

\footnotetext{
${ }^{1}$ Makmun, A. R., Sunni dan Kekuasaan Politik (Ponorogo: Ponorogo Press, 2006).
} 
based on political consensus without being preceded by bloodshed between the majority population of the City of Yathrib (The Anshor) and the minority immigrants from the City of Mecca (The Muhajirin).

After the Prophet died, the first problem that arose was political conflict. The trigger was a leadership vacuum after the Prophet's death. Until before his death, the Prophet never explicitly and appointed his successor after he died. The first dispute occurred when the Ansors unilaterally gathered at the Saqifah Bani Sa'idah and appointed Sa'ad bin Ubadah (among the Ansors) as the successor leader of the Prophet Muhammad. Seeing this, the Muhajirin made a maneuver, and under the control of Umar bin Khattab, they tried to turn the forum into the property of the Muhajirin by offering Abu Bakr Shiddiq (Muhajirin) as a person worthy of being appointed to replace the Prophet, not Sa'ad bin Ubadah. In the end, the meeting at Saqifah agreed to appoint Abu Bakr to be the new leader for the State of Medina.

The intrigue that took place at Saqifah did not escape the attention of the family of the Prophet Muhammad (ahlul bayt), especially the followers of Ali bin Abi Talib. The Ahl Bayt people say that the Prophet established leaders and even leaders after him. This means that leadership after the Prophet according to ahl bayt must be left to Ali, because all spiritual and religious issues refer to him. As a basis, they claim that the Prophet conveyed a hadith that reads: "Whoever makes me his master, Ali is his master" (man kuntu maulahu fa'aliyyu maulahu) which was delivered at Gadir Khumm after the implementation of the haj wada 'two months before the Prophet died. Ali's loyalists insisted that Ali was the most worthy person to replace the Prophet as the leader of the Muslims in the State of Medina. However, the failure of the strategy of the Bayt experts in bringing Ali to power brought prolonged disappointment. In its most obvious form, this disappointment took the form of a boycott movement from Ali and his supporters of the ceremony to make Abu Bakr become caliph.

After the era of Khalifah Rashidin, the political conflict above developed into serious divisions, because each group with different political views built theological differentiation within their respective groups. The supporters of the Saqifah meeting who appointed Abu Bakr to be caliph formed the theological foundation for what in the next era was known as Sunni, while the supporters of Ali developed the theological conception which became known as the Shi'a sect. In addition, in these two major sections, new currents emerged 
which contributed to the sharpening of divisions within the Muslim community. Ali's supporters who were disillusioned with Ali's leadership in facing Mu'awiyah's "treason" then declared the Khawarij movement as a new platform for his struggle. Not long ago, the Mu'tazillah sect was born, the group that became the strongest line against the Khawarij point of view. From the extreme dialectics of the two groups, the Murji'ah sect was born in a middle way.

From each group, some thinkers and scholars explained various aspects that differentiated them from others, both in theological, fiqh, social, cultural, and political aspects. From the system of government and leadership, Sunnis have strong preferences and a meeting point with political thought developed by Islamic intellectuals in the Classical era.

\section{METHODOLOGY}

This research is a library research, using books and journals as the main sources Literature study here is a literature study without an empirical test. The method used to collect research data is library data that has been selected, searched, presented and analyzed. This study uses data analysis techniques in the form of content analysis. Content analysis is a scientific analysis of the message content of a data.

\section{DISCUSSION}

Leadership in Islam, between the Shia and Sunni schools, has several differences, especially in defining a leader (imam / caliph), requirements for a leader, procedures for selecting a leader, sources of legitimacy for a leader, and others. For this reason, there are two perspectives, namely the theory of Imamat compiled by the Shi'a Imamiyah (followers of the twelve Shi'a Imams) and leadership in the Sunni perspective, namely (caliph).

Furthermore, Imamat means power or strength which is obeyed or followed. The word Imamat refers to the word a-m-m which means to go towards, mean to, or will. Initially, the word Imamate was a neutral term. In fact, in classical literature, the words Imamat and khilafah are used interchangeably to refer to the meaning of same meaning, namely leadership, government, and the state.

In a more specific sense, the theory of Imamat was then discussed in Shia politicalreligious thought (especially the Shi'ah Imamiyah) which developed in the 2nd century H. In 
Shia beliefs, the Imamate is a leadership system that integrates political and religious power in one institution leadership of the people. In the concept of Imamat, there is a figure of an imam (leader) as the highest authority in guiding the people towards the ultimate truth as previously Allah SWT. Raise and commission prophets among the people. For the Shi'ah, Imamat is not an area of discussion for ordinary people who are intellectually and passionately. However, the existence of an Imam is the same as the task of the prophets, and because Imamat must be based on religious arguments and texts. Imamat is not decided through deliberation (consultation), but must be based on a will.

Shia followers believe that before his death, the Prophet Muhammad had appointed Ali bin Abi Talib (the Prophet's relative and son-in-law) as his successor. Apart from these factors of closeness, Ali's spirituality and leadership are considered to be equivalent to that of the Prophet Muhammad. Therefore, the leadership of Muslims after Imam Ali must be sent down to his children, namely Imam Hasan al-Mujtaba, Imam Husain, and continued by nine descendants of Imam Husain, namely Ali Zainal Abidin, Muhammad al-Baqir, Ja'far Sadiq, Musa Kazhim, Ali Ridha, Muhammad al-Jawad, Ali al-Hadi, Hasan al-Askari, and Muhammad al-Mahdi. So the leadership follows the lineage of Ali bin Abi Talib, who has blood relations with the Prophet Muhammad, whose actions are protected from all badness.

Some of the conditions that must be attached to a priest are (a) being chosen and appointed by God, not by the general public; (b) has a scientific knowledge that includes all the knowledge that is ladunially obtained from God's side; and (c) guard against all mistakes, mistakes, and sins. From this, the belief in the concept of Imamate in the Shia tradition is one of the most basic and obligatory things to follow, because the Imamate continues the leadership of the Prophet who is tasked with providing guidance to humans, preserver, and explanation of Allah's law on earth.

In leading a country, an imam also has duties that must be carried out to achieve the prosperity of the State and its people. The scholars provide coverage on the duties which are the obligations of the Imam, namely first, to maintain and preserve religious laws, especially those concerning aqidah and to eradicate acts that smell of heresy and come out of Islamic law; second, fighting enemies who threaten the security of the State and the nation; third, regulating the income and expenditure of state finances, such as ghanimah, fai ', and obligatory shadaqah; and fourth, maintaining the security and justice of its citizens. 
Etymologically, the word "khilafah" comes from the letters "kha", "lam" and "fa"" which have three main meanings: "to replace", "behind" and "change". Al-Qur'an uses two plural forms for this word, namely "khulafa" and "khala'if" which are taken from the word "khalf" which originally meant "behind". The word "khilafah" is also a derivation of the verb "khalafa" which means "to come later", the antonym of the word "salafa" or "taqadamma" which means "passed".

In its journey, the word "khalifah" is more popularly defined as the head of state in Islam after the death of the Prophet Muhammad. However, when referring to Surat AlBaqarah verse 30, the caliph is God's representative on earth, and as Allah's representative, humans are one of the instruments for managing the earth. Allah has trusted humans to use their potential in protecting and caring for the earth.

According to Al-Shadr in Fachruroji, God's belief in humans with a caliphate on earth is due to the position of man as a unique creature among other elements in the universe who act as God's representative on earth, and through this caliphate he then becomes noble so that the angels bow down to him. Furthermore, in the verses of the Al-Qur'an, it is widely explained that the measure of glory with God is achievement and quality regardless of ethnicity and gender. This means that both men and women have the same potential as being 'abid and caliph. ${ }^{2}$

The classical era in Islamic civilization refers to the years $650-1250 \mathrm{AD}$, or from the era of the Prophet Muhammad to the era of the Abbasid dynasty. Historians then divide the classical century into two periods. The first period is the century of progress that began in 650-1000 $\mathrm{AD}$, an era marked by conquest (expansion of territory), integration and consolidation of Islamic political power, and the golden age of Islam.

The second period is referred to as the era of Islamic political disintegration which began in 1000-1250 AD. This era began before the end of the Umayyah dynasty and culminated in the Abbasid dynasty. At that time, the political institutions (caliphate) experienced a degradation of public trust and ended up in the periphery areas which chose to establish their own dynasties separately from the central power.

At the time of the beginning of Islam (the era of the Prophet and Khulafaur Rashidin) to the Umayyad Dynasty (661-750), thoughts related to Islamic politics had not yet emerged

\footnotetext{
${ }^{2}$ Moch Fachruroji, "Trilogi Kepemimpinan Islam: Analisis Teoritik terhadap Konsep Khilafah, Imamah dan Imarah", Jurnal Ilmu Dakwah 4, (2008).
} 
strongly among Islamic intellectuals. One of the contributing factors was the focus of the Umayyad dynasty which was more oriented towards developing power.

During the Abbasid dynasty, Islamic political thought began to be developed by a number of Islamic intellectuals along with the intellectual achievements of the Abbasid dynasty who succeeded in developing science in various fields. The scholars who appeared in this era include: Ibn Abi Rabi '(833-842 AD), the author of Suluk al-Malik fi Tadbir alMamalik (Behavior of Kings in the Management of Kingdoms). In addition there are also AlFarabi (870-950 AD), the author of Ara Ahl al-Madinah al-Fadhilah (Views of the Residents of the Main Country), Tahshil al-Sa'adah (The Way to Reach Happiness), and Al-Siyasah al Madaniyah (State Politics). Next, there is Al-Mawardi (975-1059 AD), the author of AlAhkam al Sulthaniyah fi al-Wilayah al-Diniyah (Government Regulations). In addition there is also Al-Ghazali (1058-1111 AD) author Ihya Ulum al-Din (Reviving Religious Science), Al-Tibr al-Masbuk fi Nashihah al-Mulk (Precious Metal Bars on Advice for Kings), AlIqtishad fi al-I'tiqad (Moderation in Belief), and Kimiya-yi Sa'adah.

One of the main characteristics of Islamic political thought in the classical era is the thick influence of the thoughts of ancient Greek philosophers, such as Plato and Aristotle, although the quality of that influence is not the same as one thinker with another thinker. This can be seen from how Islamic thinkers when formulating thoughts about the state and government that emphasize the logical aspects rather than the religious aspects, even though they still include values that come from Islamic teachings.

In his political theory, Plato stated that individual humans cannot possibly fulfill all the interests of their own lives. Therefore, cooperation and unity between individuals is needed. As a rational and social being, this cooperation creates stronger ties and leads to the formation of state institutions. This theory was later adopted by Islamic political thinkers as a philosophical construction for the formation of the state.

The next characteristic of classical era Islamic political thought is that it does not question the position of religion and state, whether integrated or separate. The debates that took place during this period only revolved around the compulsory establishment of a state, the appointment of the head of state, and the requirements for the head of state. In addition, political thought that developed in the classical era rests more on real socio-political conditions. Their thoughts are mostly born as a response to the prevailing socio-political conditions. In fact, some have based their ideas on giving legitimacy to the existing 
government system or maintaining the status quo in the interests of the authorities, only then offering suggestions for improvement and reform.

In simple terms, the mention of the Sunni term refers to the term ahlusunnah wal jama'ah, which is one of the schools in Islam that attaches religious structure (kalam), value system (tasawuf), and rituals of worship (fiqh) to the texts of the Qur'an and the sunnah of the Prophet Muhammad and his companions (especially Khulafa'ur Rasyidin) and the tabi'intabi'in generation. From this, it can be understood that the terminology of Ahlussunnah was based on the behavior of the Prophet Muhammad, and the term wal Jama'ah was based on the practice of the Companions of the Prophet and the tabi'in generation. If summarized, ahlussunnah wal Jama'ah is followers of the Prophet Muhammad, the companions, and tabi'in. Nowadays, the delivery of ahlussunnah wal Jama'ah is pronounced in different words, but still has the same meaning. Sometimes people call it Sunni, Ahlussunnah, Asy'ari, or Asy'ariah. In fact, in Indonesia, it is shortened to Aswaja.

In the history of Islamic civilization, the Sunni sect began to develop in the Khurasan area, which at that time became one of the areas not controlled by the Shia Ahlussunnah group which became popular and crystallized in the 3rd century Hijriyah or the last era of the Umayyads and the beginning of the rule of the Abbasids. This is inseparable from the context of the fragmentation of the era which was dominated by the thoughts of the Shia, Khawarij, Mu'tazillah, and Murji'ah schools, which had already established relationships with several power organizers. The ahlussunah movement was then led by a major scholar in the field of ushuluddin (kalam/theology), namely Abul Hasan 'Ali Asy'ari (873-935 AD). In the field of fiqh, the ahlussunnah mazhab followed Imam Syafi'i (767-819 AD), while in the field of Sufism the Ahlussunnah group followed Imam Ghazali (1058-1111 AD).

Anthony Black said that new Sunnis emerged from the last period of the Ummayah dynasty and the beginning of the Abbasid dynasty. The development of this movement began by targeting issues surrounding sharia (fiqh) matters. The first stage of the arrival of the Sunni group began with the collection, sorting, and rewriting of the Prophet's traditions to form an authoritative data source for Islamic praxis after the Qur'an, especially in AD $720-770 .^{3}$

The early Sunni scholars thought that the expansion of the territory and plurality of Muslims at that time had consequences on a very diverse dialectic of thought. Because of

\footnotetext{
${ }^{3}$ Anthony Black, Pemikiran Politik Islam: Dari Masa Nabi Hingga Masa Kini (Jakarta: Serambi, 2006).
} 
that, thoroughness and caution are needed in the use of religious texts such as the Al-Qur'an and Hadith. In addition, the early scholars showed a critical attitude towards the leadership of the Ummayah Dynasty, while their activities focused on hadith texts relating to spiritual, legal and personal morality issues; few touched on political issues, and only then did the issue of political authority begin to be discussed in Sunni teachings.

The embryo of the birth of this institution can be traced shortly after the deliberations at Saqifah, which failed Ali and his followers. The support of some Muslims for $\mathrm{Abu}$ Bakr, which at that time was formalized through bai'at (pledge of allegiance), automatically split Muslims in a position of facing each other, between supporters of Abu Bakr and supporters of Ali Ibn Abi Talib.

In turn, the Sunni group went through several phases before becoming an established sect as it is today. The first stage is the leadership stage of the khulafa'ur rashidin (Abu Bakr, Umar, Uthman, and Ali) which they believe to be a legitimate model of political leadership after the Prophet's death, not as propagated by the Shia.

The emergence of Sunni ideology was a form of anxiety over the views developed by groups that tended to discredit the position of the Prophet's companions, who were considered by some on the opposite side to have committed treason. For the Shia, the election of Abu Bakr, followed by the leadership of Umar and Usman, was a form of serious defiance against the orders of Allah and the Prophet Muhammad.

Ali Bin Abi Talib in their view is the most appropriate figure to replace the Prophet's position, not only because of the Ghadir Khum incident, but they strongly believe that the blood of ahl bayt that flows in Ali's body and all future descendants is a guarantee for the purity of mind and heart in the leadership process. For the Shia sect, the purity of the Qur'an, hadith, the balance of the universe, the safety of the Muslims in general, can only be carried by Ali and his descendants.

In brief, one of the principles that distinguish Shia from Sunnis is that the Shia believe that Ali and his descendants (later called the Imams) inherited kema'suman (holy from sin) from the Prophet Muhammad so that the milestone of spiritual and political leadership should be continued by Ali and his descendants. Meanwhile, Sunnis argue that leadership after the Prophet's death was open and not limited to Ahl Bayt. Whatever the background, if it is deemed appropriate and competent, it can be proposed to be a leader. 
During the era of the Caliph Rashidin and the era of the Umayah dynasty, it was not known that Islamic political thought was formulated systematically. And only appeared in the period of the Abbasid dynasty. However, the procedure for the appointment of khulafaur rasyidin through ijma 'by friends and Muslims became the basis for the preparation of future Islamic political theorists, especially political thinkers from the Sunni circles.

There are several important starting points in discussing the history of Islamic politics, starting from the death of the Prophet Muhammad without a will regarding his successor, the negotiations at Saqifah Bani Saidah; the implementation of Shura 'was the first time to find a replacement for the position of the Prophet Muhammad, until the Tahkim incident (arbitration) between Ali and Muawiyah. The various impacts and analysis of these events led Muslims to an incontrovertible fact, namely the polarization of the power of the ummah in the aftermath.

The political characteristics of Sunni thinkers usually show siding with the authorities. The opinions and arguments they built were often a means of legitimacy to justify the Caliph's power at that time. For example, the concept of the caliphate as described by Al-Mawardi in his book Al-Ahkam as-Sulthaniyah, which states that the function of the caliph is not only a substitute for leadership but as a substitute for prophetic function. This is made the ruler justify any action taken by him. ${ }^{4}$

Another characteristic of Sunni political thought is the granting of privileges to the Quraish tribe which a candidate for head of state absolutely must-have. Their view is based on the Prophet's hadith which states that the imams (leaders) of the Muslims must come from the tribe of Quraish.

A common and significant characteristic of Sunni thought is that there is no procedure for removing a caliph. Their dry and of course legalistic approach contradicts the theory of Imamat which tends to be metaphysical which is believed by Shi'ah followers and as philosophers. Ahlusunnah's view of the caliph was further developed by the followers of as-Syafi'i, namely Abu Hasan Al-Mawardi (974-1058 AD). It attempted to address the sharp gap between religious leadership and coercive power by reconnecting the de facto rulers of the sultans and emirs with the Abbasid caliphate.

${ }^{4}$ I. Al-Mawardi, Al Ahkam Al Sulthaniyah: Hukum-Hukum Penyelenggaraan Negara dalam Syariat Islam (Bekasi: Darul Falah, 2014). 
State and government institutions exist as a substitute for prophetic functions in safeguarding religion and governing the world. The appointment of a head of state to lead Muslims is obligatory according to ijma'. If the leadership of this country is obligatory, then the obligation is kifayah, such as jihad and seeking knowledge. If there are people who run from among the competent people, then that obligation falls on other people, and if no one is in office then this obligation is differentiated between two groups of people, namely those who have the authority to elect the head of state for the Muslim community and to people who have the competence to lead the country so that they appoint one of them to hold this position.

The origin of a country, it is said that basically, humans are social creatures who cannot fulfill all their needs individually. Furthermore, Plato stated that the state was formed because of cooperation between people in fulfilling their daily needs. The increasingly wellorganized community of life and cooperation formed the state. This theory was later also agreed upon and adopted by Islamic political thinkers, such as Ibn Arrabi, Al-Farabi, and AlMawardi.

Ibn Arabi began his discussion of a country or city based on social reality, that humans are the kind of creatures who need each other to fulfill all their needs and themselves can't meet their daily needs without help or side by side from and with others. Therefore, one another needs each other to get the necessities of life. Desire is sufficient to survive, and to obtain it requires cooperation, encouraging them to gather in a place so that they can help each other to help and give. It was this process that led to the formation of cities and ultimately states.

Al-Farabi (870-950 AD) also argued that every human being naturally needs many things that not all of them can be fulfilled by themselves, in order to maintain (existence) and achieve the highest perfection. Everything that is needed by all people to defend themselves and achieve perfection (can) be collected and distributed in an association.

Al-Mawardi (975-1059M) also argued that humans are social creatures, and someone can't be able to fulfill their own needs unless they are related to other people. However, slightly different from Ibn Arabi and Al-Farabi, Al-Mawardi strengthened the theory of the formation of a state based on fulfilling one need met by another. To fulfill all these needs then humans agree based on common interests and guided by the rules that bind them, 
namely religious law, in an institution or institution called the state (al-Daulah, al-Shultanah, al-Khalifah, and others- other.

For Al-Mawardi, an Islamic state is considered good if it fulfills six main principles, namely: First, the religion that is lived. Religious belief functions as a moral force capable of controlling human desires and passions. This requirement is the main pillar as well as controlling and controlling the various human desires. Second, charismatic rulers (authoritative). A ruler is required to have charisma, dignity, and be exemplary. Charismatic rulers can foster and organize the country to achieve noble goals, namely creating justice and prosperity for the people, keeping religion lived and practiced, protecting the lives, wealth and honor of citizens, and ensuring the existence of the state from threats that arise either from internal and external.

Third, thorough justice. Justice is a very important condition because with equitable justice the friendship of fellow citizens is created, raises respect and obedience to leaders, enlivens people's lives, and fosters the work and achievements of society. Fourth, equal security. With strong and guaranteed security, people will feel calm and have no fear. Security is the main requirement for the running of a country. When a sense of security and calm is created, people will be more obedient to their leaders.

Fifth, sustainable soil fertility. Soil fertility can guarantee the food needs of citizens. With certainty in doing business and seeking the necessities of life for the people, the state must create a situation and conditions that are conducive to the development of the state and people's businesses so that the people can live decent and prosperous lives. This condition is the purpose and implementation of the previous terms. ${ }^{5}$

The survival of the next generation and generation is very dependent on the state management system by state managers and administrators with qualifications as found sequentially in the previous joints. The current generation is the heir of the previous generation and the generation that created history for the aftermath.

In terms of the form of the state, Ibn Arabi agreed with Aristotle who argued that the monarchy system was the best system of government. The reason is the king has all the virtues of being a leader beyond the virtues of ordinary citizens. The king is the law, the source, and the implementation of the law, because he has the ability and political power more than anything else. Ibn Arabi quoted a verse from the Qur'an (Surat al-An'am verse

\footnotetext{
${ }^{5}$ I. Al-Mawardi, Al Ahkam Al Sulthaniyah, (2014).
} 
165) which means: and it is He who made you the rulers of the earth and He exalted some of you over some (others) several degrees, to test you about which he gave you. So, the basis for the authority and power of a leader is a mandate from God or a task given by God with a special position in the form of virtue and excellence.

The central theme in classical Islamic political discourse is leadership. In the Islamic tradition, there are two approaches used when talking about leadership, namely the Imamate and the Khilafah. The concept of Imamat is a concept shared by the Shi'ah and the concept of khilafah is closer to that of the Sunnis. The term Imamat means power or strength which is obeyed or followed. According to Black, the meaning of the priest is the evidence of God; are the pillars of the universe, the "gates" through which to draw closer to God. Knowledge of divine revelation depends on it. ${ }^{6}$

As a concept, the debate about the Imamate was started by supporters of Ali bin Abi Talib who later became a Shiite sect. This occurred when Ali was not chosen to be caliph to replace the Prophet, Muhammad. The Shi'ah reduce the concept of Imama to belong to the descendants of the Prophet Muhammad alone, which in this case belongs to Ali, which is then passed on to his descendants. They took refuge behind the Prophet's ma'shuman according to them also passed down to the descendants afterward.

The Sunnis then fought against the theological claims made by the Shiites. Sunni scholars developed a conceptualization of the caliphate as a counterpoint to the Imamate. In the Sunni view, the caliph as the legitimate ruler in managing his people, his appointment depends on the specific qualities that must be possessed by the ruler. In the view of Abul Hasan al-Asy'ari (873-935 AD), a Sunni theologian, the caliphate is needed to uphold religion and maintain world order, while establishing the Imamate is a syar'i obligation. Then base his thoughts on Q.S. al-Nisa verse 59 which contains orders to obey Allah, the apostle, and the government. It seems to him that politics and religion are two things that complement each other and have not many different functions: to create an orderly social life. Al-Mawardi also stated that the caliphate was formed to replace the prophetic function in order to maintain religion and rule the world. Thus an imam is a religious leader on the one hand and a political leader on the other.

The election of the head of state (caliph) is a very urgent and vital issue for the existence of the state. However, Islam did not regulate how leadership succession should be

\footnotetext{
${ }^{6}$ Anthony Black, Pemikiran Politik Islam, (2006).
} 
carried out, which resulted in divisions among Muslims. In looking at the debates and conflicts surrounding the election of Abu Bakr shortly after the Prophet's death, al-Asy'ari saw that Abu Bakr's leadership was legitimate and must be obeyed. The election of Abu Bakr was not without reason, because it fulfilled several elements needed in selecting a leader: theological foundation (Al-Qur'an and hadith), capability and competence, agreement (ijma) of friends, and pledge of allegiance from society (bai ' at). Al-Farabi emphasized the necessity of having a head of state in a community system. The head of state is likened to his position like the heart in the human body, as the source and center of coordination between organs in the body, so that humans reach the degree of perfection. Therefore, the position of the head of state is not only political but also ethical as a way of life controller. Furthermore, Al-Farabi said that the destruction of a country was caused by the moral factor of its leader.

Al-Farabi then detailed the criteria that a head of state must have: (1) perfect limbs; (2) great understanding in understanding; (3) good catching power; (4) perfect memory; (5) proficient and wise in speaking; (6) love knowledge; (7) is not greedy in drinking, food and sex; (8) love the truth and hate lies; (9) love justice and hate injustice; (10) does not live in luxury and pleasure; (11) able to uphold justice, optimistic and generous; and (12) strong in mind, full of courage, enthusiasm, and not stunted.

For Al-Mawardi, an imam or caliph (who in his mind is a king, president, sultan) is something necessary. That is, its existence is very important in a society or country. Therefore, without a priest, chaos arose. Humans become dignified, so also a nation becomes worthless. Al-Mawardi stated the main points. First, Imamat is a leadership formed as a substitute for the Prophet, with the task of maintaining religion and controlling world life. Second, Imamat can be formed through elections by an assembly capable of solving problems and establishing policies or al-ikhtiyar (council of voters) consisting of individuals who meet certain requirements. Third, if an imam has carried out his duties and obligations, the people are obliged to declare loyalty and obedience to him, obey and support his political policies, and defend him from those who want to get rid of or keep him away. However, a priest can be removed from his position if he deviates from justice. Fourth, the head of state must be an Arab national from the Quraish tribe, including the wazir tafwidh (assistant to the head of state) in matters of policy formulation must be of Arab ethnicity, and the filling of the position of head of state and strategic assistant requires certain conditions to be 
enforced. According to him, the prerogative of the Quraish tribe was supported by the words of the Prophet: Put the Quraish first and don't precede him. ${ }^{7}$

In the matter of dismissing an imam, Al-Mawardi mentioned two things that changed his condition and therefore had to resign from his position. First, defects injustice (can be caused by lust, or due to subhat). Second, disabilities, which in this case are sensory defects (including defects that prevent a person from being appointed as a priest, such as permanent memory loss, vision loss). Apart from that, there are organ defects and deformities in action. Meanwhile, some defects do not prevent a person from being appointed as a priest, such as a nose defect that causes you to be unable to smell something, taste defects, such as distinguishing the taste of food. ${ }^{8}$

\section{CONCLUSION}

After the Prophet Muhammad died, the first problem that confronted Muslims was political conflict. The trigger was a leadership vacuum after the death of the Prophet Muhammad. Until before his death, the Prophet never explicitly and appointed his successor if he died. After the leadership of the four caliphs passed, the political conflicts that plagued the Muslim community grew into serious divisions, because each group with different political views built theological differentiation within their respective groups, both in terms of theology, fiqh, social, culture and political.

The emergence of Sunni ideology itself was a form of anxiety over the views developed by groups that tended to discredit the position of the Prophet's companions who were considered by some on the opposite side to have committed treason. For Sunnis, leadership after the death of the Prophet Muhammad was open and not limited to only ahl Bayt. Whatever his background, if he is deemed worthy and competent, he can be proposed as a leader. Thus, the appointment or appointment of the caliph as the legal ruler depends on the specific qualities possessed by the prospective leader.

\footnotetext{
${ }^{7}$ I. Al-Mawardi, Al Ahkam Al Sulthaniyah, (2014).

${ }^{8}$ Ibid.
} 


\section{REFERENCES}

Abbas, S. (2010). I'tiqad Ahlussunnah Wal Jama'ah. Jakarta: Pustaka Tarbiyah Baru.

Akbar, Idil. (2017). "Khilafah Islamiyah: Antara Konsep dan Realitas Kenegaraan (Republik Islam Iran dan Kerajaan Islam Arab Saudi)". Journal of Government and Civil Society, 1(1).

Ali, S. M. (2007). Hussain The King of Marytyrs Raja Para Syuhada. Jakarta: Lentera Hati.

Al-Mawardi, I. (2014). Al Ahkam Al Sulthaniyah: Hukum-Hukum Penyelenggaraan Negara dalam Syariat Islam. Bekas: Darul Falah.

Amin, N. (2017). Paradigma Teologi Politik Sunni, Melacak Abu Al Hasan Al Asy’ari. Yogyakarta: Pustaka Pelajar.

Amin, S., \& Siregar, F. M. (2015). “Pemimpin dan Kepemimpinan dalam Al-Qur'an”. Tanzil: Jurnal Studi Al-Qur'an.

Amini, I. (2005). Semua Perlu Tahu. Jakarta: Al Huda.

Arfiansyah. (2010). "Pemikiran Politik Islam: Sebuah Tinjauan Sejarah Terhadap Arus Pemikiran Islam Klasik sampai Awal Abad ke 20”. Substantia, 12(2).

Black, Anthony. (2006). Pemikiran Politik Islam: Dari Masa Nabi Hingga Masa Kini. Jakarta: Serambi.

Fachruroji, Moch. (2008). “Trilogi Kepemimpinan Islam: Analisis Teoritik terhadap Konsep Khilafah, Imamah dan Imarah.” Jurnal Ilmu Dakwah 4(12).

Fadli, Yusuf. (2017). "Islam, Perempuan dan Politik: Argumentasi Keterlibatan Perempuan dalam Politik di Indonesia Pasca Reformasi”. Journal of Government and Civil Society, 1(1).

Hakiki, Kiki Muhamad. (2012). "Mengkaji Ulang Sejarah Politik Kekuasaan Abbasiyah". Jurnal Tapis 9(1).

Hughes, T. P. (1982). Dictionary of Islam. New Delhi: Cosmo Publication.

Ja'farian, R. (2009). Sejarah Islam: Sejak Wafat Nabi SAW Hingga Runtuhnya Dinasti Bani Umayyah. Jakarta: Lentera.

Jafri, H. M. (1979). Origin and Early Development of Shi'a Islam. New York: Longman.

Katsir, I. (2002). Bidayah Wa Nihaya: Masa Khulafa'ur Rasyidin. Jakarta: Darul Haq.

Makmun, A. R. (2006). Sunni dan Kekuasaan Politik. Ponorogo: Ponorogo Press.

Munawwir, A. W. (1984). Al-Munawwir (Kamus Arab-Indonesia). Surabaya: Pustaka 
Nasution, H. (1986). Teologi Islam: Aliran-aliran Sejarah Analisa Perbandingan. Jakarta: UI Press.

Nasution, H. (2008). Islam Ditinjau dari Berbagai Aspeknya. Jakarta: UI Press Progressif.

Ritaudin, M. Sidi. (2009). “Spirit Islam Politik Periode Al-Khulafa Al-Rasyidun bagi Negara Kesatuan Republik Indonesia”. Jurnal Tapis 5(10).

Rusli, Ris'an. (2015). “Imamah: Kajian Doktrin Syi’ah dan Perdebatan Pemikiran Islam Klasik". Intizar 21(2).

Sjadzali, M. (1999). Islam dan Tata Negara: Ajaran, Sejarah dan Pemikiran. Jakarta: UI Press.

Sunanto, M. (2003). Sejarah Islam Klasik: Perkembangan Ilmu Pengetahuan Islam. Jakarta: Kencana.

Syarif, M. I. (2008). Fiqh Siyasah: Doktrin dan Pemikiran Politik Islam. Jakarta: Erlangga.

Thabathaba'i, M. (1989). Islam Syi'ah: Asal-Usul dan Perkembangannya. Jakarta: Grafiti Press.

Thabathaba'i, M. (1992). Inilah Islam. Bandung: Pustaka Hidayah.

Zahrah, M. A. (2010). Aliran Politik dan Aqidah dalam Islam. Jakarta: Gaya Media Pratama. 